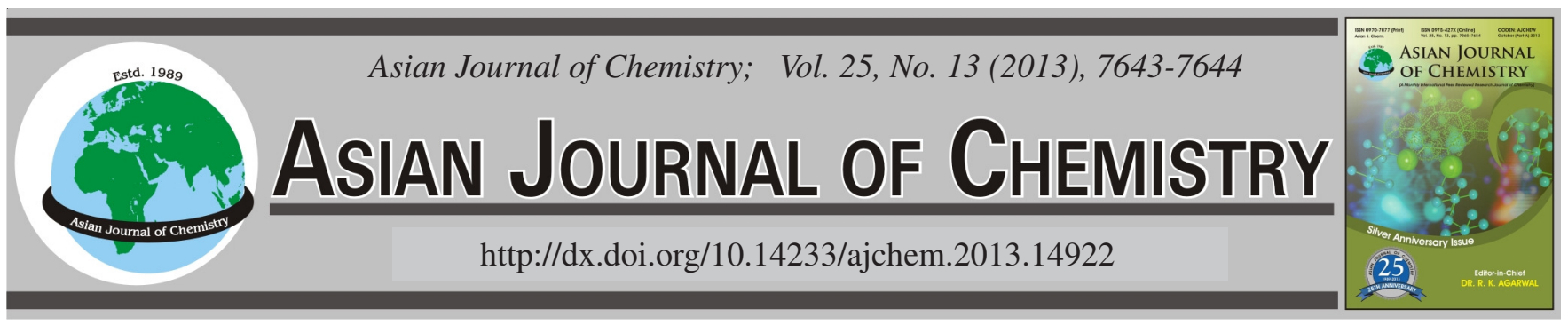

NOTE

\title{
Synthesis and Crystal Structure of a Cu(II) Complex with a Thiazole Containing Derivative of 1,5-Diazacyclooctane
}

Qiang Xu* ${ }^{*}$ Ru-Hua Zha, Jiang-Ping Meng, Zhao-Dong Wang and Feng-Ming Chen

School of Materials and Chemical Engineering, Chongqing University of Arts and Sciences, Yongchuan, Chongqing 402160, P.R. China

*Corresponding author: Tel: +86 23 61162728; E-mail: xuq18@sina.com

(Received: 5 December 2012;

Accepted: 5 July 2013)

AJC-13775

\begin{abstract}
A new binuclear $\mathrm{Cu}(\mathrm{II})$ complex $\left[\mathrm{Cu}_{2}(\mathrm{~L})_{2} \cdot\left(\mathrm{H}_{2} \mathrm{O}\right) \cdot\left(\mathrm{ClO}_{4}\right)\right]\left(\mathrm{ClO}_{4}\right)_{3}\left(\mathrm{~L}=1,5\right.$-bis- $\left(5 \mathrm{H}-1 \lambda^{4}\right.$-thiazol-4-ylmethyl)-1,5-diazocane $)$ was synthesized and characterized by elemental analysis, IR spectroscopy and X-ray analysis. The complex crystallizes in orthorhombic system, space group P2(1)2(1)2(1) with $\mathrm{a}=14.931(5), \mathrm{b}=16.041(6), \mathrm{c}=18.700(7), \mathrm{V}=4479(3) \AA^{3}, \mathrm{Dc}=1.720 \mathrm{~g} / \mathrm{Cm}^{3}, \mathrm{Z}=4, \mathrm{~F}(000)=2368, \mu\left(\mathrm{MoK}_{\alpha}\right)$ $=0.71073 \mathrm{~mm}^{-1}, \mathrm{R}=0.0738$ and $w R=0.1460$ for 7885 observed reflections $(I>2 \sigma(I))$. X-ray analysis reveals that both copper(II) metal ion display a square pyramidal geometry with different coordination modes. Each copper is five-coordinated by four $\mathrm{N}$ from the ligand and one $\mathrm{O}$ form water molecule in $\mathrm{Cu}(1)$ and one $\mathrm{O}$ atom from perchlorate anion in $\mathrm{Cu}(2)$, respectively.
\end{abstract}

Key Words: Copper(II) complex, 1,5-Diazacyclooctane ligand, Thiazole, Crystal structure.

ᄂ - - - - - - - - - - - - - - - - - - - - - - - - - -

Macrocyclic polyamine and their transitional metal complexes have been well studied for past several decades. Much attention and work have been focused on the studies of macrocyclic tri- and tetraamine, such as 1,4,7-triazacyclododecane ([9]aneN3), 4,1,4,8,11-tetraazacyclotetradecane (cyclam). As the smallest family members of macrocyclic polyamine, the coordination chemistry of 1,5-diazacyclooctane (DACO) and its functionalized derivatives was reported several decades ago. The incorporation of one or two functional donors into the $\mathrm{N}$ atoms of the diamine enriched the coordination modes of the ligands with the metal and led to the formation of interesting metal complexes. Many derivatives of 1,5-diazacyclooctane with different functional group, such as $-\mathrm{CH}_{2} \mathrm{CO}_{2-},-\mathrm{CH}_{2} \mathrm{CH}_{2} \mathrm{SH}$ and $-\mathrm{CH}_{2}$-pyridyl and their metal complexes have been reported $^{1-4}$. However, rare derivative bearing with thiazole petant was reported, here we synthesized and characterized a thiazole containing derivative of 1,5-diazacyclooctane and the structure of its copper complex.

1,5-Diazacyclooctane and chloromethylthiazole hydrochloride were prepared according to the literature methods. Other reagents were purchased from Aldrich and used without further purification. Elemental analyses for $\mathrm{C}, \mathrm{H}$ and $\mathrm{N}$ were carried out on a Perkin-Elmer 204 analyzer. X-ray crystallography was carried out using a Bruker SMART APEX II CCD dffractometer. Infrared spectra were carried out using a Nicolet FT-IR170SX spectrograph. Melting point was carried out using an X-6 precision microscopic melting point meter.
${ }^{1} \mathrm{H}$ NMR was carried out using a Bruker $300 \mathrm{MHz}$ nuclear magnetic resonance spectrometer.

Synthesis of the ligand (L): 1,5-Diazacyclooctane-2HBr (1.38 g, $5 \mathrm{mmol}$ ) and potassium hydroxide (2.24 g, $40 \mathrm{mmol})$ were dissolved in absolute ethyl alcohol $(30 \mathrm{~mL})$. The mixture was stirred at room temperature for $2 \mathrm{~h}$. Then it was heated to a refluxing when chloromethylthiazole hydrochloride $(1.7 \mathrm{~g}$, $10 \mathrm{mmol})$ dissolved in absolute ethyl alcohol $(30 \mathrm{~mL})$ was added drop by drop to react for another $3 \mathrm{~h}$. The above mixture was stirred at room temperature overnight, yellow oily liquid was formed after slow decompression evaporation of the solvent and faint yellow oily liquid was formed after further column chromatography separation $\left(\mathrm{CH}_{2} \mathrm{Cl}_{2}: \mathrm{CH}_{3} \mathrm{OH}: \mathrm{NH}_{3} \cdot \mathrm{H}_{2} \mathrm{O}\right.$ $=5: 5: 1$ ). The faint yellow oily liquid was dissolved in a small amount of absolute ethyl alcohol and the dry $\mathrm{HCl}$ gas was flowed, then cream-coloured solid precipitation was separated out immediately. The final ligand $\mathrm{L}$ was obtained by the filtration, vacuum drying. Yield: $1.62 \mathrm{~g}(71 \%)$. m.p.: $138.5-140.4{ }^{\circ} \mathrm{C} .{ }^{1} \mathrm{H}$ NMR ( $\left.{ }_{2} \mathrm{O}, 400 \mathrm{MHz}\right): 9.02$ (s, 2H), 7.83 (s, 2H), 4.52 (s, 4H), 3.49 (bs, 8H), 2.28 (bs, 4H) ppm. IR (KBr, $\left.v_{\max }, \mathrm{cm}^{-1}\right)$ : 3040, 2960, 2560, 2000, 1640, 1480, 1115, 1100, 950, 900, 850.

Synthesis of the Complex: $\left[\mathrm{Cu}_{2}(\mathrm{~L})_{2} \cdot\left(\mathrm{H}_{2} \mathrm{O}\right) \cdot\left(\mathrm{ClO}_{4}\right)\right]\left(\mathrm{ClO}_{4}\right)_{3}$ : The ligand $\mathrm{L}(100 \mathrm{mg}, 0.22 \mathrm{mmol})$ was dissolved in a small amount of methanol $(15 \mathrm{~mL})$, the solution of sodium hydroxide was added till the $\mathrm{pH}$ of the mixture close to 8 with slow stirring. Then the methanol solution of $\mathrm{Cu}\left(\mathrm{ClO}_{4}\right)_{2} \cdot 6 \mathrm{H}_{2} \mathrm{O}(93 \mathrm{mg}$, $0.22 \mathrm{mmol}$ ) was added to the above mixture, leading to the 
formation of a dark blue solution. The solution was heated to reflux for $2 \mathrm{~h}$ and cooled to room temperature. After the filtration, slow evaporation of the dark blue filtrate resulted in the formation of dark blue crystal suitable for X-ray analysis over a period of two weeks. Yield: $73 \mathrm{mg}(57 \%)$, IR ( KBr, $\mathrm{v}_{\max }$, $\mathrm{cm}^{-1}$ ): 3120, 2880, 1640, 1440, 1320, 1240, 1080, 960, 880, 840. Anal. calcd. (\%) for $\mathrm{C}_{28} \mathrm{H}_{42} \mathrm{~N}_{8} \mathrm{O}_{17} \mathrm{~S}_{4} \mathrm{Cl}_{4} \mathrm{Cu}_{2}: \mathrm{C}, 29.00 ; \mathrm{H}$, $3.65 ; \mathrm{N}, 9.66$. Found (\%), C, 29.32; H, 3.55; N, 9.54.

The selected bond lengths and bond angles are listed in Table- 1 and hydrogen bond length and angle in Table- 2 . The crystal structure of the copper(II) complex is shown in Fig. 1. It contains two separated mononuclear copper cations with different coordination environment and three perchlorate anions. Each copper is five-coordinated by four $\mathrm{N}$ atoms from the ligand and one $\mathrm{O}$ atom from water molecule in $\mathrm{Cu}(1)$ and one $\mathrm{O}$ atom from perchlorate anion in $\mathrm{Cu}(2)$, respectively. Both coppers display a square pyramidal geometry. The $\mathrm{Cu}-\mathrm{N}$ distances are in the range of $2.001(6) \AA-2.058(5) \AA$, the axial $\mathrm{Cu}-\mathrm{O}$ distances are longer than the basal $\mathrm{Cu}-\mathrm{N}$ distances. The presence of the $\mathrm{O}-\mathrm{H} \cdots \mathrm{O}$ hydrogen bonding between the coordinated $\mathrm{H}_{2} \mathrm{O}$ or $\mathrm{ClO}_{4}^{-}$and the anionic perchlorate can stabilize the structure of the complex.

\begin{tabular}{|c|c|c|c|}
\hline \multicolumn{4}{|c|}{$\begin{array}{l}\text { TABLE- } 1 \\
\text { SELECTED BOND LENGTHS (Å) AND BOND } \\
\text { ANGLES }\left({ }^{\circ}\right) \text { OF THE TITLE COMPLEX }\end{array}$} \\
\hline Bond & Length $(\AA)$ & Bond & Angle $\left({ }^{\circ}\right)$ \\
\hline $\mathrm{Cu}(1)-\mathrm{N}(1)$ & $2.001(6)$ & $\mathrm{N}(2)-\mathrm{Cu}(1)-\mathrm{N}(1)$ & $100.6(2)$ \\
\hline $\mathrm{Cu}(1)-\mathrm{N}(2)$ & $2.4069(14)$ & $\mathrm{N}(2)-\mathrm{Cu}(1)-\mathrm{N}(3)$ & $84.0(2)$ \\
\hline $\mathrm{Cu}(1)-\mathrm{N}(3)$ & $2.058(5)$ & $\mathrm{N}(2)-\mathrm{Cu}(1)-\mathrm{O}(1)$ & $96.5(2)$ \\
\hline $\mathrm{Cu}(2)-\mathrm{O}(2)$ & $2.282(5)$ & $\mathrm{N}(3)-\mathrm{Cu}(1)-\mathrm{O}(1)$ & $108.1(2)$ \\
\hline $\mathrm{Cu}(1)-\mathrm{N}(4)$ & $2.028(6)$ & $\mathrm{N}(5)-\mathrm{Cu}(2)-\mathrm{N}(7)$ & $158.8(3)$ \\
\hline $\mathrm{Cu}(1)-\mathrm{O}(1)$ & $2.221(5)$ & $\mathrm{N}(7)-\mathrm{Cu}(2)-\mathrm{N}(8)$ & $87.4(3)$ \\
\hline $\mathrm{Cu}(2)-\mathrm{N}(5)$ & $2.013(6)$ & $\mathrm{N}(7)-\mathrm{Cu}(2)-\mathrm{O}(2)$ & 100.1(3) \\
\hline $\mathrm{Cu}(2)-\mathrm{N}(6)$ & $2.002(5)$ & $\mathrm{N}(2)-\mathrm{Cu}(1)-\mathrm{N}(4)$ & $167.2(2)$ \\
\hline $\mathrm{Cu}(2)-\mathrm{N}(7)$ & $2.038(6)$ & $\mathrm{N}(1)-\mathrm{Cu}(1)-\mathrm{N}(3)$ & $154.6(2)$ \\
\hline \multirow[t]{11}{*}{$\mathrm{Cu}(2)-\mathrm{N}(8)$} & $2.055(5)$ & $\mathrm{N}(1)-\mathrm{Cu}(1)-\mathrm{O}(1)$ & $96.3(2)$ \\
\hline & & $\mathrm{N}(6)-\mathrm{Cu}(2)-\mathrm{N}(5)$ & $101.3(2)$ \\
\hline & & $\mathrm{N}(6)-\mathrm{Cu}(2)-\mathrm{N}(8)$ & $165.6(2)$ \\
\hline & & $\mathrm{N}(6)-\mathrm{Cu}(2)-\mathrm{O}(2)$ & $96.4(2)$ \\
\hline & & $\mathrm{N}(8)-\mathrm{Cu}(2)-\mathrm{O}(2)$ & $96.4(2)$ \\
\hline & & $\mathrm{N}(1)-\mathrm{Cu}(1)-\mathrm{N}(4)$ & $82.4(2)$ \\
\hline & & $\mathrm{N}(4)-\mathrm{Cu}(1)-\mathrm{N}(3)$ & $88.1(2)$ \\
\hline & & $\mathrm{N}(4)-\mathrm{Cu}(1)-\mathrm{O}(1)$ & $95.6(2)$ \\
\hline & & $\mathrm{N}(6)-\mathrm{Cu}(2)-\mathrm{N}(7)$ & $83.9(3)$ \\
\hline & & $\mathrm{N}(6)-\mathrm{Cu}(2)-\mathrm{N}(8)$ & $88.61(5)$ \\
\hline & & $\mathrm{N}(5)-\mathrm{Cu}(2)-\mathrm{O}(2)$ & $99.8(3)$ \\
\hline
\end{tabular}

TABLE-2

HYDROGEN BOND LENGTHS $(\AA)$ AND BOND ANGLES $\left({ }^{\circ}\right)$

\begin{tabular}{lcccc}
\hline $\mathrm{D}-\mathrm{H} \cdots \mathrm{A}$ & $\mathrm{d}(\mathrm{D}-\mathrm{H})$ & $\mathrm{d}(\mathrm{H} \cdots \mathrm{A})$ & $\mathrm{d}(\mathrm{D} \cdots \mathrm{A})$ & $\angle \mathrm{DHA}$ \\
\hline $\mathrm{O}(9)-\mathrm{H}(9 \mathrm{~A}) \cdots \mathrm{O}(5)^{\mathrm{a}}$ & 0.868 & 1.868 & $2.728(18)$ & $171(2)$ \\
$\mathrm{O}(9)-\mathrm{H}(9 \mathrm{~B}) \cdots \mathrm{O}(2)^{\mathrm{b}}$ & 0.873 & 1.936 & $2.796(2)$ & $168(2)$ \\
$\mathrm{O}(10)-\mathrm{H}(10 \mathrm{~A}) \cdots \mathrm{O}(11)^{\mathrm{c}}$ & 0.857 & 1.993 & $2.795(2)$ & $155(2)$ \\
\hline
\end{tabular}
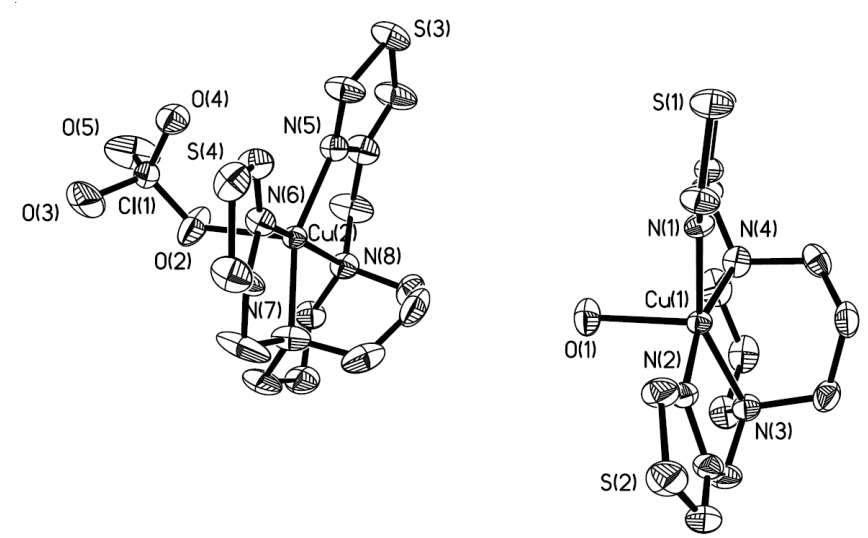

Fig. 1. Molecular structure of the cationic part of the title complex, showing the atom-numbering scheme. $\mathrm{H}$ atoms have been omitted for clarity

\section{Conclusion}

In this paper, we synthesized and characterized a rare thiazole containing deravative of 1,5-diazacyclooctane. The copper complex of this ligand was obtained and characterized by X-ray analysis. It was consisted of two separated mononuclear copper unit, the presence of the hydrogen bonding contribute to the stabilization of the complex.

\section{ACKNOWLEDGEMENTS}

The authors thank the support from Science and Technology Project of Chongqing Municipal Education Commission (KJ071208).

\section{REFERENCES}

1. X.H. Bu, M. Du, Z.L. Shang, R.H. Zhang, D.Z. Liao, M. Shionyya and T. Clifford, Inorg. Chem., 39, 4190 (2000).

2. X.H. Bu, M. Du, L. Zhang, D.Z. Liao, J.K. Tang, R.H. Zhang and M. Shionoya, J. Chem. Soc., Dalton Trans., 593 (2001).

3. X.H. Bu, M. Du, L. Zhang, Z.L. Shang, R.H. Zhang and M. Shionoya, , J. Chem. Soc., Dalton Trans., 729 (2001).

4. M. Du, X.H. Bu, Y.M. Guo, L. Zhang, D.Z. Liao and J. Ribas, Chem. Commun., 10, 1478 (2002). 